\title{
Leptin resistance following over-expression of protein tyrosine phosphatase 1B in liver
}

\author{
N T Lam, S D Covey ${ }^{1}$, J T Lewis, S Oosman ${ }^{1}$, T Webber ${ }^{1}$, E C Hsu², A T Cheung ${ }^{2}$ and \\ T J Kieffer ${ }^{1}$ \\ Department of Medicine, University of Alberta, Edmonton, Alberta, Canada \\ ${ }^{1}$ Laboratory of Molecular and Cellular Medicine, Departments of Cellular and Physiological Sciences and Surgery, Life Science Institute, University of British Columbia, \\ Vancouver, British Columbia V6T 1Z3, Canada \\ enGene Inc., Vancouver, British Columbia, Canada
}

(Requests for offprints should be addressed to T J Kieffer; Email: tim.kieffer@ubc.ca)

\begin{abstract}
Obesity is typically associated with resistance to leptin, yet the mechanism by which leptin signaling becomes impaired is poorly understood. Here we sought to determine if the development of obesity and leptin resistance correlates with increased expression of protein tyrosine phosphatase 1B (PTP1B) in peripheral tissues and whether over-expression of this phosphatase, specifically in liver, could alter the leptin-mediated effects on feeding and glucose metabolism. Obesity was induced in mice through a high-fat diet that resulted in hyperglycemia, hyperinsulinemia and hyperleptinemia. Resistance to leptin was confirmed as exogenous leptin administration reduced food intake in animals on low-fat, but not high-fat diets. Diet-induced resistance to leptin and insulin was associated with increased hepatic levels of PTP1B. Intriguingly, hepatic adenoviral over-expression of PTP1B in ob/ob mice attenuated the ability of exogenous leptin to reduce both plasma glucose levels and food intake. These findings suggest that leptin reduces both plasma glucose and food intake in part through actions on the liver, and hepatic leptin resistance resulting from over-expression of PTP1B may contribute to the development of both diabetes and obesity.
\end{abstract}

Journal of Molecular Endocrinology (2006) 36, 163-174

\section{Introduction}

Hormone signaling typically involves a balance between signaling activators and inhibitors. The stimulatory effects of protein tyrosine kinases and the inhibitory effects of protein tyrosine phosphatases largely define the action of insulin. Appropriate insulin signaling minimizes large fluctuations in blood glucose concentrations and ensures adequate delivery of glucose to cells. Therefore a signaling imbalance whereby the inhibitory actions of the phosphatases prevail causes insulin resistance and hyperglycemia which, if left untreated, may lead to diabetes mellitus. Leptin signaling is similarly regulated; signaling begins with phosphorylation and activation of janus kinase 2 (JAK2) (Ghilardi \& Skoda 1997) and ends with the dephosphorylation and deactivation of JAK2 (Cheng et al. 2002, Zabolotny et al. 2002). Leptin, an important satiety factor, functions both in hypothalamic satiety centers and peripherally as an accountant of caloric consumption and energy expenditure and is important in body weight regulation and maintenance of normal glucose and fatty acid homeostasis (Friedman \& Halaas 1998, Ahima \& Flier 2000, Unger 2002). Resistance to leptin is associated with weight gain and elevated blood glucose levels. The mechanisms that cause leptin and insulin signaling pathways to become imbalanced have not been established.

Insulin signal transduction begins with insulin-induced autophosphorylation of tyrosine residues in the insulin receptor (IR). Protein tyrosine phosphatase 1B (PTP1B) attenuates insulin signaling by dephosphorylating IR (Ahmad et al. 1995, Elchebly et al. 1999, Zinker et al. 2002). Mice lacking the PTP1B gene $\left(\mathrm{PTP}_{1} \mathrm{~B}^{-/-}\right.$) exhibit enhanced insulin sensitivity (Elchebly et al. 1999, Klaman et al. 2000), and PTP1B antisense oligonucleotides can improve insulin sensitivity and normalize blood glucose levels in diabetic mice (Zinker et al. 2002, Gum et al. 2003). Surprisingly, $\mathrm{PTP}_{1} \mathrm{~B}^{-/-}$mice are also resistant to weight gain when given a high-fat (HF) diet (Elchebly et al. 1999, Klaman et al. 2000). This might be in part due to the fact that these animals have enhanced sensitivity to leptin. JAK2 has been shown to be a substrate of PTP1B in cell lines (Myers et al. 2001, Kaszubska et al. 2002) and PTP1B negatively regulates leptin signaling in hypothalamic satiety centers by dephosphorylating JAK2 in vivo (Cheng et al. 2002, Zabolotny et al. 2002). Given the dual role of PTP1B in attenuating leptin and insulin signaling, there is great interest in pursuing PTP1B inhibition to treat both 
obesity and diabetes (Johnson et al. 2002, Zhang \& Lee 2003). However, the relative importance of PTP1B activity in regulating leptin signaling in peripheral tissues has not been established. To explore the relevance of peripheral PTP1B expression to the actions of leptin, we have here examined leptin function in animals in which hepatic PTB1B levels are elevated, either by an HF diet or with an adenoviral vector.

\section{Materials and methods}

\section{Animals and diets}

Mice were maintained by the University of Alberta Health Sciences Laboratory Animal Services; they were housed individually on a $12 \mathrm{~h}$ light: $12 \mathrm{~h}$ darkness cycle with ad libitum access to food. All animal studies were approved by the Health Sciences Animal Policy and Welfare Committee, University of Alberta, Edmonton, Canada. The low-fat (LF) diet contained $11 \% \mathrm{~K}$ Cal from coconut oil (D12328; Research Diets Inc., New Brunswick, NJ, USA) and the HF diet contained 58\% kcal from coconut oil (D12330; Research Diets Inc.).

\section{Hormone and metabolite assays}

Plasma glucose concentrations were measured with a kit from Diagnostic Chemicals Ltd (Charlottetown, Prince Edward Island, Canada) and plasma insulin and leptin were measured using ELISA kits (American Laboratory Products Co., Windham, NH, USA). Within experiments, samples were measured in a single assay to eliminate inter-assay variation. All samples were measured in triplicate.

\section{HF diet study}

Three-week-old male C57BL/6 mice were provided ad libitum access to an LF diet for 7 days. Following the 7-day acclimatization period, mice were either continued on the LF diet $(n=8)$ or transferred to an HF diet $(n=11)$. Body weights and food intake were measured daily, and after 35 days on either the LF or HF diet mice were fasted for $4 \mathrm{~h}$ at the start of the light cycle and blood samples were collected for determination of plasma glucose, insulin and leptin levels. After 70 days on either the LF or HF diet either PBS (LF diet $n=4, \mathrm{HF}$ diet $n=5$ ) or $2.5 \mu \mathrm{g} / \mathrm{g}$ recombinant murine leptin (Pepro Tech Inc., Rocky Hill, NJ, USA) (LF diet $n=4$, HF diet $n=6)$ was administered twice daily (0900 and $1600 \mathrm{~h}$ ) by i.p. injection for 2 days. During these 2 days the mice remained on the respective diets and were monitored daily for food consumption, body weight, plasma glucose and plasma insulin. After the 2 days of leptin or PBS treatment mice were fasted for $4 \mathrm{~h}$ at the start of the light cycle and then anesthetized with $50 \mathrm{mg} / \mathrm{kg}$ ketamine hydrochloride/xylazine (Bimeda-MTC Animal Health Inc., Cambridge, Ontario; Canada/Bayer Inc., Toronto, Ontario, Canada) and $25 \mathrm{mU} / \mathrm{kg}$ human insulin was infused in the portal vein. Two minutes after insulin infusion the epididymal fat pads, soleus plantaris, and gastrocnemius muscles and liver were excised and frozen in liquid nitrogen. Protein lysates were prepared for later analysis.

\section{Ob/ob mouse study}

Seventeen eight-month-old $o b / o b$ male mice (C57BL/6JLepob; Jackson Laboratories, Bar Harbor, ME, USA) were fasted for $4 \mathrm{~h}$ at the start of the light cycle, and body weight, food consumption, plasma glucose and plasma insulin levels were measured. Mice were then anesthetized by isofluorane inhalation and $1 \times 10^{9}$ plaque-forming units (PFU) of adenoviruses expressing either PTP1B (AdPTP1B) $(n=10)$ or $\beta$-galactosidase (Ad $\beta$-gal) $(n=7)$ were administered as a single tail vein injection. At 2, 5 and 6 days after virus infection mice were fasted for $4 \mathrm{~h}$ at the start of the light cycle and body weight, food consumption, plasma glucose and plasma insulin levels were measured. On day 6 following measurement of the above-mentioned parameters, mice were given either PBS (AdPTP1B $n=4$ ) or $0.5 \mu \mathrm{g} / \mathrm{g}$ recombinant murine leptin (AdPTP1B $n=6, \operatorname{Ad} \beta$-gal $n=7)$ twice daily $(0900$ and $1600 \mathrm{~h}$ ) by i.p. injection for 2 days. The lower dosage of leptin in this study relative to the study with the C57BL/6 mice was because of the hypersensitivity of $o b / o b$ mice to leptin. We have previously found that this dose of leptin does not affect body weight after 2 days of administration but does affect food consumption (Lam et al. 2004). Body weight, food consumption, plasma glucose and plasma insulin levels were measured daily for the next 2 days. Six hours following the last treatment, mice were anesthetized by isofluorane inhalation and $25 \mathrm{mU} / \mathrm{kg}$ human insulin was infused in the portal vein. Two minutes after insulin infusion part of the liver tissue was excised and frozen in liquid nitrogen. Protein lysates were made for later analysis. In addition, from the Ad $\beta$-gal-infected mice $(n=7)$, liver, pancreas, brain, muscle, heart, kidney and spleen tissues were excised and immediately embedded in Tissue-Tek OCT compound (IMEB Inc., San Marcos, CA, USA) and immersed slowly in $\mathrm{CO}_{2}$ /ethanol above liquid nitrogen.

\section{Protein immunoblotting}

Protein lysates were prepared and immunoblotting was performed as previously described (Lam et al. 2004). For analysis of tyrosine phosphorylation of the $\beta$-subunit of IR (IR $\beta), 2 \mathrm{mg}$ protein lysate was immunoprecipitated with rabbit polyclonal anti-IR $\beta$ (sc-71; Santa Cruz Biotechnology, Inc., Santa Cruz, CA, USA) and 
protein A-conjugated beads (Pierce Chemical Company, Rockford, IL, USA). Immunoprecipitates were washed, separated by SDS-PAGE and transferred to nitrocellulose. Membranes were immunoblotted with monoclonal mouse anti-phosphotyrosine antibody (PY99; sc-7020; Santa Cruz Biotechnology, Inc.) followed by goat anti-mouse secondary antibody conjugated to horseradish peroxidase (HRP) (sc-2005; Santa Cruz Biotechnology, Inc.). Protein content was visualized by enhanced chemiluminescence (ECL detection kit; Amersham Pharmacia, Uppsala, Sweden). The total amount of IR $\beta$ chain was determined by stripping the membranes and re-blotting with rabbit polyclonal anti-IR $\beta$ (sc-711; Santa Cruz Biotechnology, Inc.) and donkey polyclonal anti-rabbit antibody conjugated to HRP (NA934; Amersham Pharmacia) and proteins were visualized as described above. Analysis of tyrosine phosphorylation of STAT3 was performed as previously described (Lam et al. 2004) by immunoprecipitating $750 \mu \mathrm{g}$ protein lysate with polyclonal rabbit anti-STAT3 antibodies (sc-482; Santa Cruz Biotechnology, Inc.) and immunoblotting with monoclonal mouse anti-phosphotyrosine (sc-7020; Santa Cruz Biotechnology, Inc.). Proteins were visualized as described above. To determine the total amount of STAT3, membranes were stripped and re-blotted with polyclonal rabbit anti-STAT3 (sc-482; Santa Cruz Biotechnology, Inc.) and proteins visualized as described above. PTP1B and Src homology 2-contininag phosphatase-2 (SHP2) immunoblotting was performed with polyclonal goat anti-PTP1B (sc-1718; Santa Cruz Biotechnology, Inc.) and polyclonal rabbit anti-SHP2 (sc-424; Santa Cruz Biotechnology, Inc.). Polyclonal rabbit anti-goat (AP106P; Chemicon International Inc., Temecula, CA, USA) and polyclonal donkey anti-rabbit (NA934; Amersham Pharmacia) HRPconjugated antibodies were used for PTP1B and SHP2 immunoblotting respectively. Proteins were visualized as described above. Densitometry on immunoblots was performed with Molecular Dynamics ImageQuant software (Amersham Pharmacia Biotech, Uppsala, Sweden).

\section{Construction and propagation of recombinant adenovirus}

The recombinant adenoviruses containing PTP1B or $\beta$-gal cDNA, generously provided by Drs J Wang, J K Kolls and M Bryer-Ash (Egawa et al. 2001, Wang et al. 2001), were propagated and titered as previously described (Lam et al. 2004). The adenovirus has a high degree of hepatotropism, and when delivered intravenously results in highly specific liver expression.

\section{Adenovirus infection of $\mathrm{CHO}$ cells}

$\mathrm{CHO}$ cells over-expressing the leptin receptor b (OBRb) were a kind gift from Dr T Murakami (Murakami et al.
1997), and were cultured as previously described (Lam et al. 2004). For infection with adenovirus, cells in $100 \mathrm{~mm}$ plates at $60 \%$ confluence were incubated for $15 \mathrm{~min}$ in $2 \mathrm{ml}$ Dulbecco's PBS (D-PBS; Life Technologies Inc., Burlington, Ontario, Canada) with $4.3 \mathrm{mM}$ calcium (D-PBS-Ca ${ }^{2+}$ ) containing $6.7 \times 10^{9}$ PFU of either Ad $\beta$-gal or AdPTP1B. Following $48 \mathrm{~h}$ of infection, cells were incubated in serum-free media for $4 \mathrm{~h}$ then treated with vehicle or recombinant murine leptin $(10 \mathrm{ng} / \mathrm{ml})$ for $15 \mathrm{~min}$ and washed twice in ice-cold D-PBS-Ca ${ }^{2+}$. Cells were then harvested and protein lysates were prepared for immunoblotting.

\section{Immunocytochemistry}

Immunocytochemistry of STAT3 in CHO OBRb cells cultured on glass coverslips was performed as previously described (Lam et al. 2004) using anti-STAT3 (sc-482; Santa Cruz Biotechnology, Inc.).

\section{$\beta$-galactosidase staining}

Tissues from $a b / o b$ mice in OCT compound were processed into $10 \mu \mathrm{m}$ sections and fixed with $0 \cdot 2 \%$ glutaraldehyde for $5 \mathrm{~min}$. Slides were washed in PBS and incubated for $4 \mathrm{~h}$ at $37^{\circ} \mathrm{C}$ with $\mathrm{X}$-gal solution $(1 \mathrm{mg} / \mathrm{ml}$ 5-bromo-4-chloro-3-indolyl $\beta$-D-galactopyranoside (Promega Corp., Madison, WI, USA), $5 \mathrm{mM}$ potassium ferricyanide, $5 \mathrm{mM}$ potassium ferrocyanide and $2 \mathrm{mM} \mathrm{MgCl}_{2}$, in PBS) (all from Sigma-Aldrich Canada Inc., Oakville, Ontario, Canada). Slides were washed twice in PBS and examined with a Leica DMIRB microscope (Leica Microsystems, Germany).

\section{Real-time PCR}

CD1 male mice (8-9 weeks old) were either uninfected or infected with $1 \times 10^{9} \mathrm{PFU}$ Ad $\beta$-gal. Seven days after infection, hypothalamus and liver samples were extracted and genomic DNA isolated using DNeasy Tissue kits (Qiagen, Mississauga, Ontario, Canada). Quantitative detection of the $\beta$-gal gene was performed by real-time PGR using Applied Bioscience sequence detection system 7000 (Foster City, CA, USA). Reactions consisted of genomic DNA template, TaqMan Universal PCR Master Mix (Applied Biosciences) and the following primers (TAC TGT CGT CGT CGC GTG AAA), (TAA CAA CGC GTG GGA TTG TGG) and probe. 6-carboxyfluorescein (6 FAMTAT CGC ATT AGG GTC AAT GGG CGGMGBNFQ) (Applied Biosciences). PCRs were initiated at $50{ }^{\circ} \mathrm{C}$ for $2 \mathrm{~min}$ and $95^{\circ} \mathrm{C}$ for $10 \mathrm{~min}$ and then 40 cycles of $95^{\circ} \mathrm{C}$ for $15 \mathrm{~s}$ and $60{ }^{\circ} \mathrm{C}$ for $1 \mathrm{~min}$. Results were analyzed with $\mathrm{ABI}$ Prism software (Applied Biosciences) and the number of copies of the $\beta$-galactosidase gene was determined by the standard curve method. 


\section{Statistical analysis}

Group differences were evaluated by paired $t$-test or ANOVA analyses with GraphPad Prism software (GraphPad Software Inc., San Diego, CA, USA), with $P<0 \cdot 05$ deemed significant.

\section{Results}

\section{HF feeding induces hyperglycemia, hyperinsulinemia and hyperleptinemia in C57BL/6 mice}

Daily caloric intake by mice on the HF diet was slightly elevated compared with mice on the LF diet (Fig. 1B), resulting in $\sim 15 \%$ increase in cumulative calories consumed after 72 days on the diets $(912 \cdot 5 \pm 31 \cdot 1$ vs $788.5 \pm 36.5 \mathrm{kcal}$ ) (Fig. 1C). At the end of the 72 days, HF-fed mice weighed $\sim 25 \%$ more than LF-fed mice $(35 \cdot 5 \pm 0 \cdot 6$ vs $28 \cdot 0 \pm 1 \cdot 2 \mathrm{~g}$ ) (Fig. 1A). Differences in body weight became significant by day 18 on the diets (HF: $25 \cdot 1 \pm 0.3$ vs LF: $23.5 \pm 0.7 \mathrm{~g}, P<0.025)$ while changes in cumulative food intake were significant by day 16 (HF: $201 \pm 1 \cdot 7$ vs LF: $186 \cdot 3 \pm 4 \cdot 0 \mathrm{kcal}$, $P<0.002)$. Consistent with an increase in body mass, mice fed the HF diet had a greater than 5-fold increase in plasma leptin levels relative to the LF-fed mice after 35 days on the respective diets $(P<0 \cdot 05$; Table 1$)$. Since weight gain can be associated with insulin resistance, plasma glucose and insulin levels were measured after 35 days on the diets. Consistent with the development of insulin resistance, plasma glucose and insulin were elevated in HF-fed mice by $23 \%$ and $59 \%$ respectively $(P<0 \cdot 05$; Table 1$)$.

\section{HF feeding reduces the effects of leptin on food consumption in C57BL/6 mice}

Prior to leptin treatment and 70 days into the HF diet, these mice were $\sim 25 \%$ heavier than the LF-fed mice (Table 2). After 2 days of treatment with either PBS or leptin $(2.5 \mu \mathrm{g} / \mathrm{g})$ twice daily, there were no changes in body weights in any treatment group. However, leptin reduced food consumption by $50 \%$ following 2 days of treatment in LF-fed mice. In comparison, PBS-treated LF-fed mice displayed no changes in food consumption. Although leptin suppressed feeding in LF-fed mice, it had no effect on food intake in HF-fed mice (Table 2). At this dose of leptin, serum glucose concentrations were not affected in either group. However, leptin dramatically reduced plasma insulin levels after day 2 by $\sim 50 \%$ in LF-fed mice and $\sim 40 \%$ in HF-fed mice. While consistent with improvements in insulin sensitivity, the improvement was not to the same level in the HF-fed mice as insulin levels remained more than three times higher in this group compared with the LF-fed leptin-treated group.
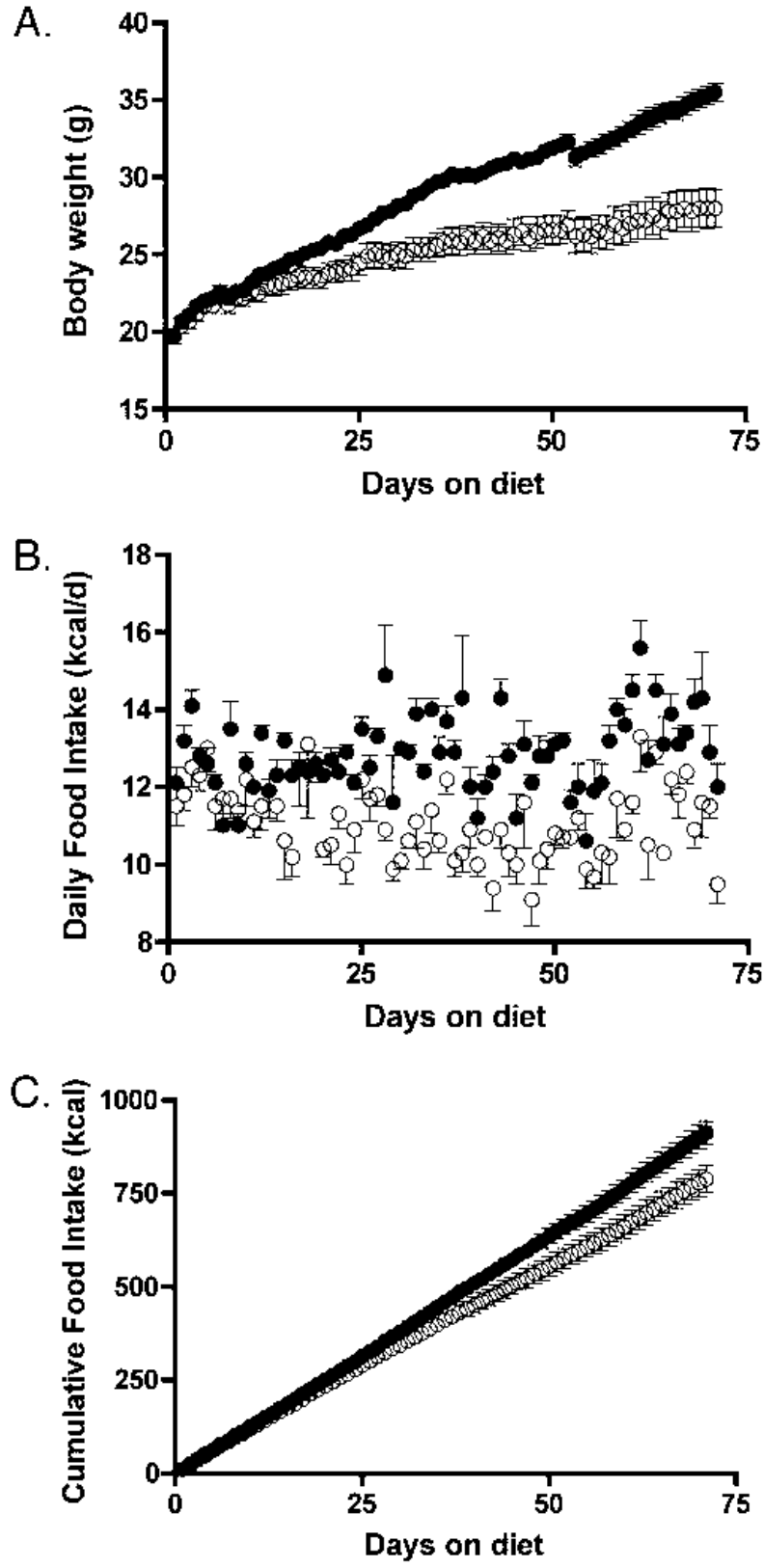

Figure $1 \mathrm{HF}$ feeding increases body weight and food consumption. C57BL/6 mice were fed ad libitum diets consisting of either LF or HF. Body weight and food consumption was measured daily for 72 days. (A) Body weight, (B) daily caloric consumption and (C) cumulative caloric consumption in mice fed diets consisting of LF (open circles, $n=8$ ) and HF (closed circles, $n=11$ ) plotted as means \pm S.E.M.

\section{HF feeding leads to hepatic insulin resistance and elevated PTP1B protein expression in liver, muscle and adipose tissue}

Consistent with an insulin-resistant state, mice on the HF diet had reduced liver IR phosphorylation compared 
Table $1 \mathrm{HF}$ feeding induces hyperglycemia, hyperinsulinemia and hyperleptinemia in C57BL/6 mice. Mice were kept for 35 days on the diet indicated and parameters were measured after a $4 \mathrm{~h}$ fast. Values are means \pm S.E.M.

\section{Diet}

\section{Parameter}

Plasma glucose $(\mathrm{mM})$

Plasma insulin (pM)

Plasma leptin $(\mathrm{ng} / \mathrm{mL})$

${ }^{*} P \leq 0 \cdot 05$

with mice on the LF diet (pTyr (phosphotyrosine)/IR densitometric ratios for LF vs HF: $0.82 \pm 0.06$ vs $0 \cdot 54 \pm 0 \cdot 16 ; P<0 \cdot 05)$ (Fig. 2). Since phosphatases have been implicated as negative regulators of both insulin and leptin signaling, we determined whether HF feeding affects the expression of PTP1B or SHP2 in liver, skeletal muscle and adipose tissue. Expression of PTP1B was increased in adipose, muscle and liver tissues in HF-fed mice relative to LF-fed mice. While the 1·6-fold increase in PTP1B expression in adipose tissue was not statistically significant $(P<0 \cdot 06)$, the 2 -fold increase in PTP1B expression in muscle and 6.4-fold increase in liver in the HF-fed group was significant $(P<0 \cdot 05)$ (Fig. 3). In comparison, SHP2 protein levels in these same tissues were relatively constant, with the exception of adipose tissue where there was a small increase.
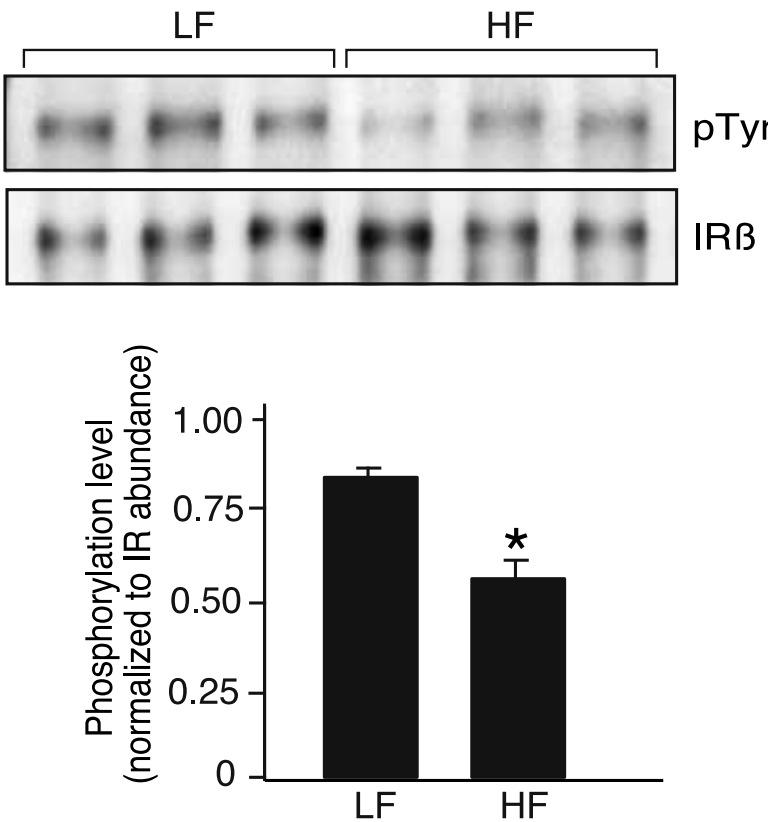

Figure $2 \mathrm{HF}$ feeding decreases insulin-stimulated IR phosphorylation in liver tissue. C57BL/6 mice fed either LF or HF diets were fasted for $6 \mathrm{~h}$, and then given an infusion of insulin $(25 \mathrm{mU} / \mathrm{kg})$ via the hepatic portal vein. Two minutes following the insulin infusion, liver tissue was harvested and protein lysates prepared and then immunoprecipitated with antibody to IR. Phosphorylation of IR was assessed by immunoblotting with anti-phosphotyrosine antibody. Membranes were stripped and reprobed with IR antibody. Representative immunoblots depicting tyrosine phosphorylation of a $95 \mathrm{kDa}$ IR $\beta$-subunit are shown. Below the immunoblots is shown the mean \pm S.E.M. intensities (arbitrary units) of phosphotyrosine corrected for total IR $(n=3) .{ }^{*} P<0.05$.

Table 2 HF diet reduces the effects of leptin $(2.5 \mu \mathrm{g} / \mathrm{g}$ twice daily) on food consumption in C57BI/6 mice. Day 0 is after 70 days on the indicated diet. Parameters were measured after a $4 \mathrm{~h}$ fast. Values are means \pm S.E.M.

\begin{tabular}{|c|c|c|c|c|c|}
\hline & \multirow[b]{2}{*}{ Diet } & \multirow[b]{2}{*}{ Treatment } & \multicolumn{3}{|c|}{ Leptin treatment period } \\
\hline & & & Day 0 & Day 1 & Day 2 \\
\hline \multicolumn{6}{|l|}{ Parameter } \\
\hline \multirow[t]{4}{*}{ Body weight (g) } & LF & PBS & $27 \cdot 1 \pm 1 \cdot 4$ & $27 \cdot 7 \pm 2 \cdot 1$ & $27 \cdot 4 \pm 1.9$ \\
\hline & LF & Leptin & $28 \cdot 8 \pm 2 \cdot 2$ & $28 \cdot 6 \pm 1.9$ & $27 \cdot 3 \pm 1 \cdot 8$ \\
\hline & HF & PBS & $33 \cdot 6 \pm 0.6$ & $33 \cdot 7 \pm 0 \cdot 6$ & $33 \cdot 1 \pm 0.6$ \\
\hline & $\mathrm{HF}$ & Leptin & $36 \cdot 5 \pm 0.4$ & $36 \cdot 8 \pm 0 \cdot 4$ & $36 \cdot 5 \pm 0 \cdot 3$ \\
\hline \multirow[t]{4}{*}{ Food intake (kcal/day) } & LF & PBS & $11 \cdot 8 \pm 0 \cdot 8$ & $12 \cdot 2 \pm 0 \cdot 0$ & $11 \cdot 4 \pm 0 \cdot 0$ \\
\hline & LF & Leptin & $10 \cdot 6 \pm 0 \cdot 4$ & $10 \cdot 2 \pm 0 \cdot 0$ & $5 \cdot 3 \pm 0 \cdot 4^{*} \dagger$ \\
\hline & HF & PBS & $12 \cdot 2 \pm 0 \cdot 6$ & $11 \cdot 1 \pm 0 \cdot 6$ & $10 \cdot 0 \pm 0 \cdot 6$ \\
\hline & HF & Leptin & $13 \cdot 9 \pm 1 \cdot 1$ & $12 \cdot 8 \pm 0 \cdot 6$ & $11 \cdot 1 \pm 0 \cdot 6$ \\
\hline \multirow[t]{4}{*}{ Plasma glucose (mM) } & LF & PBS & $9.5 \pm 0.9$ & $6 \cdot 9 \pm 0.7$ & $7 \cdot 8 \pm 0 \cdot 8$ \\
\hline & LF & Leptin & $10 \cdot 1 \pm 0 \cdot 6$ & $10 \cdot 8 \pm 1 \cdot 1$ & $9 \cdot 9 \pm 1 \cdot 0$ \\
\hline & $\mathrm{HF}$ & PBS & $10 \cdot 9 \pm 0 \cdot 4$ & $11 \cdot 0 \pm 0 \cdot 6$ & $11 \cdot 6 \pm 1 \cdot 8$ \\
\hline & HF & Leptin & $11 \cdot 9 \pm 0.6$ & $10 \cdot 6 \pm 1 \cdot 0$ & $9 \cdot 2 \pm 1 \cdot 0$ \\
\hline \multirow[t]{4}{*}{ Plasma insulin (pM) } & LF & PBS & $133 \pm 8$ & $145 \pm 29$ & $204 \pm 38$ \\
\hline & LF & Leptin & $125 \pm 22$ & $110 \pm 8$ & $60 \pm 3^{*}$ \\
\hline & $\mathrm{HF}$ & PBS & $259 \pm 64$ & $192 \pm 38$ & $330 \pm 46$ \\
\hline & $\mathrm{HF}$ & Leptin & $370 \pm 57$ & $427 \pm 37$ & $220 \pm 23^{*}$ \\
\hline
\end{tabular}

LF PBS: $n=4$; LF leptin: $n=4$; HF PBS: $n=5$; HF leptin, $n=6$.

${ }^{*} P \leq 0.05$ vs day 0 of same treatment group. $\dagger P \leq 0.05$ vs day 1 of same treatment group. 

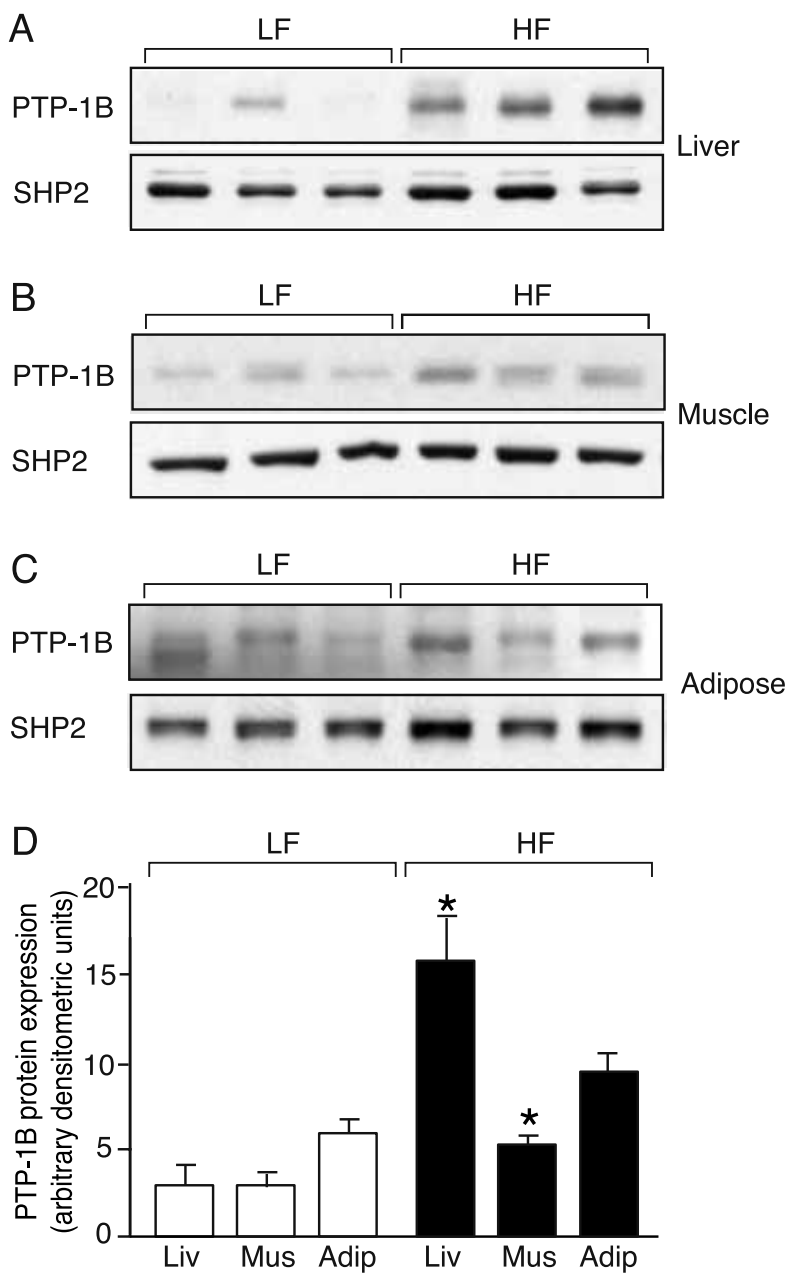

Figure $3 \mathrm{HF}$ feeding increases PTP1B expression in a tissueand phosphatase-specific manner. Protein lysates prepared from tissues extracted from C57BL/6 mice after 72 days of feeding on either LF (open bars) or HF (solid bars) diets were immunoblotted with antibodies to either PTP1B or SHP2. Immunoblots showing PTP1B (50 kDa) and SHP2 (68 kDa) protein expression are shown for $(A)$ liver, $(B)$ skeletal muscle and $(C)$ adipose tissue. (D) Densitometric analysis of PTP1B protein expression in immunoblots $(A, B$ and $C$ ) expressed as the densitometric averages \pm S.E.M. in arbitrary units for liver (Liv), muscle (Mus) and adipose (Adip) tissue from mice on LF and HF diets ( $n=3$ for LF, $n=5$ for HF). ${ }^{*} P<0.05$.

\section{PTP1B over-expression in CHO OBRb cells inhibits STAT3 phosphorylation and nuclear translocation by leptin}

While leptin treatment resulted in $\sim 10$-fold higher STAT3 phosphorylation in comparison with vehicle treatment in control Ad $\beta$-gal-infected cells, PTP1B over-expression suppressed this effect (Fig. 4A). Furthermore, in contrast to Ad $\beta$-gal-infected cells, PTP1B over-expression excluded STAT3 from the nucleus, even in the presence of leptin (Fig. 4B).

\section{Adenovirus-mediated over-expression of PTP1B in livers of $o b / o b$ mice has minimal effects on glucose homeostasis for 5 days after infection}

To directly assess the in vivo impact of elevated hepatic PTP1B expression on leptin sensitivity, glucose homeostasis, body weight and food intake, AdPTP1B or Ad $\beta$-gal was administered to leptin-sensitive but -deficient $a b / o b$ mice. Following administration of AdPTP1B or Ad $\beta$-gal, there was a trend towards a decrease in food intake in all groups (significant only in the AdPTP/PBS group), likely attributable to the effects of the procedure (Table 3). By day 5 after adenovirus administration, food consumption was only slightly reduced and not significantly different from preinfection values in any group. There were also no differences in body weight or plasma glucose levels compared with previrus values (Table 3). Similarly, plasma insulin levels were comparable in all groups between preinfection and 2 days post infection as well as on day 6 prior to leptin/PBS treatment (insulin levels at 5 days post infection were not measured). In order to determine the tissue distribution of the virally encoded genes, $\beta$-gal staining was performed on extracted tissues. Approximately $40 \%$ of hepatocytes showed blue staining while there was minimal staining in all other tissues examined, including the pancreas and brain (Fig. 5). Given the documented suppressive action of PTP1B on leptin signaling in the hypothalamus (Cheng et al. 2002, Zabolotny et al. 2002), we also evaluated the extent to which gene delivery by systemic delivery of adenovirus could result in expression in the hypothalamus, using TaqMan real-time PCR. As expected, the livers from Ad $\beta$-gal-infected mice contained significant amounts of the $\beta$-gal gene (Fig. 5). In contrast, the hypothalamus from the corresponding mice contained levels of the $\beta$-gal gene comparable with uninfected controls, indicating that it is unlikely for our observations described below to be attributable to altered PTP1B expression in the hypothalamus following the delivery of AdPTP1B. In AdPTP1B mice, liver PTP1B protein levels were $\sim 5$ times greater than in mice receiving Ad $\beta$-gal, confirming liver over-expression of PTP1B (Fig. 6A).

\section{Increased PTP1B expression in livers of ob/ob mice inhibits the effects of leptin on food consumption and blood glucose concentrations}

On day 6 after infection, mice were treated with PBS or leptin $(0 \cdot 5 \mu \mathrm{g} / \mathrm{g})$ by i.p. injection twice daily for 2 days. Leptin, at this dose and administration period, had no effect on body weight in either group but significantly reduced food intake by $\sim 50 \%$ in animals that received Ad $\beta$-gal (Table 3). In comparison, food consumption in AdPTP1B-infected mice was only reduced by $20 \%$, 
A
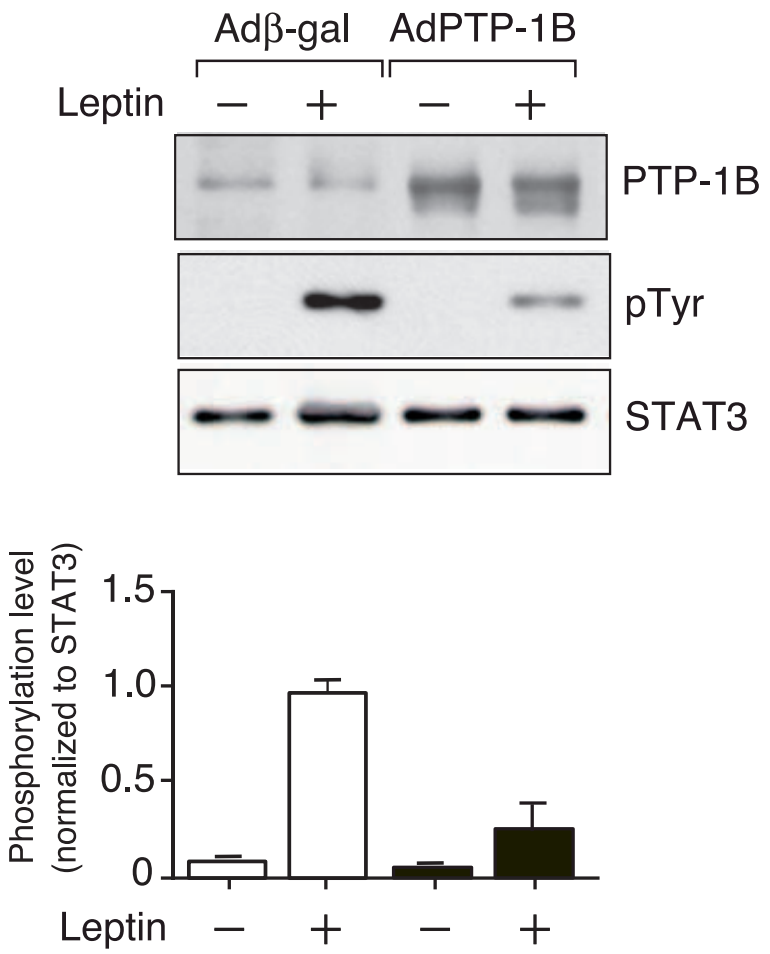

B

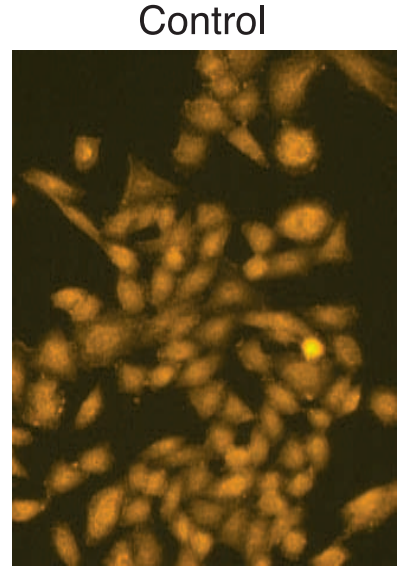

Ad $\beta$-gal + Leptin

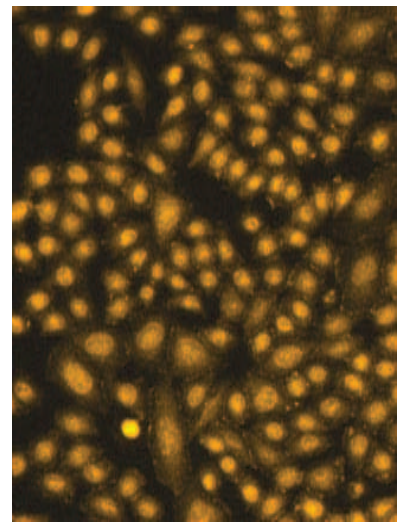

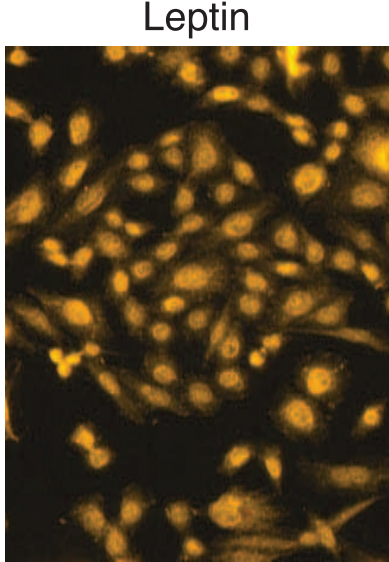

AdPTP1B + Leptin

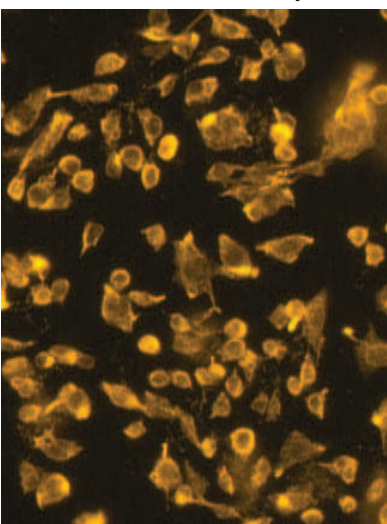

Figure 4 PTP1B over-expression in CHO OBRb cells inhibits STAT3 phosphorylation and nuclear translocation by leptin. CHO OBRb cells were infected with Ad $\beta$-gal (open bars) or AdPTP1B (solid bars) for a $48 \mathrm{~h}$ period. Cells were then incubated in serum-free media for $4 \mathrm{~h}$ and treated with vehicle or recombinant murine leptin $(10 \mathrm{ng} / \mathrm{ml})$ for $15 \mathrm{~min}$. (A) Protein lysates prepared from infected $\mathrm{CHO}$ OBRb cells either immunoblotted with anti-PTP1B antibody or immunoprecipitated with antibody to STAT3 and immunoblotted with anti-phosphotyrosine antibody. Phosphotyrosine blots were then stripped and reprobed with STAT3 antibody. Representative immunoblots are shown as well as the mean \pm S.E.M. intensities (arbitrary units) of phosphotyrosine expression, corrected for total STAT3 protein \pm S.E. $(n=2)$. (B) Immunofluorescent detection of STAT3 in CHO OBRb cells treated with PBS (control), leptin $(10 \mathrm{ng} / \mathrm{ml})$ or leptin following infection with Ad $\beta$-gal or AdPTP1B.

not reaching statistical significance. Therefore, overexpression of PTP1B in the liver alone suppressed the ability of leptin to induce satiety in $o b / o b$ mice. Similarly, leptin reduced fasting serum glucose concentrations by $\sim 50 \%$ in Ad $\beta$-gal mice $(P<0 \cdot 05)$ and $\sim 20 \%$ in AdPTP1B mice (not significant), indicating a role of PTP1B in preventing leptin from normalizing high glucose levels. Interestingly, leptin was equally capable of reducing serum insulin concentrations in both Ad $\beta$-gal- and AdPTP1B-treated mice to $\sim 35 \%$ of day 0 concentrations. Additionally, we looked at whether PTP1B over-expression affected leptin-mediated improvements in insulin sensitivity at the level of the IR in the liver (Fig. 6). IR phosphorylation in response to insulin is dramatically reduced in insulin-resistant $o b / o b$ mice compared with wild-type lean, insulin-sensitive mice, and is virtually normalized following 2 days of leptin treatment (Lam et al. 2004). In the current study, mice were treated with insulin following leptin or PBS treatment. In leptin- and Ad $\beta$-gal-treated mice, insulin induced IR phosphorylation. In contrast, insulin was unable to stimulate IR phosphorylation in leptin-treated AdPTP1B mice (Fig. 6B).

\section{Discussion}

There is a strong association of type 2 diabetes with obesity such that approximately $80 \%$ of patients with type 2 diabetes are obese (Olefsky 1983). Insulin and leptin resistance are hallmarks of obesity and risk factors for the development of diabetes, yet a common mechanism linking the resistance to these hormones is yet to be identified. In agreement with earlier studies 
Table 3 Increased PTP1B expression in livers of ob/ob mice inhibits the effects of leptin on food consumption and blood glucose concentrations. 8-month-old ob/ob mice received $1 \times 10^{9}$ PFU Ad $\beta$-gal or AdPTP1B on day 0; 6 days later PBS or leptin (0.5 $\mu$ g/g twice daily) was given for 2 days. Parameters were measured after a $4 \mathrm{~h}$ fast. Values are means \pm S.E.M.

\begin{tabular}{|c|c|c|c|c|c|c|c|}
\hline & \multirow[b]{2}{*}{ Treatment } & \multicolumn{3}{|c|}{ Adenovirus administration } & \multicolumn{3}{|c|}{ Leptin treatment period } \\
\hline & & Day 0 & Day 2 & Day 5 & Day 0 & Day 1 & Day 2 \\
\hline \multicolumn{8}{|l|}{ Parameter } \\
\hline \multirow[t]{3}{*}{ Body weight (g) } & AdPTP1B/PBS & $51 \cdot 3 \pm 3 \cdot 2$ & $51 \cdot 7 \pm 3 \cdot 2$ & $51 \cdot 9 \pm 3 \cdot 0$ & $51 \cdot 4 \pm 3 \cdot 1$ & $52 \cdot 0 \pm 3 \cdot 0$ & $51 \cdot 9 \pm 3 \cdot 0$ \\
\hline & AdPTP1B/leptin & $59 \cdot 8 \pm 4 \cdot 3$ & $60 \cdot 4 \pm 4 \cdot 2$ & $60 \cdot 3 \pm 3 \cdot 9$ & $59 \cdot 8 \pm 4 \cdot 1$ & $59 \cdot 9 \pm 4 \cdot 0$ & $58 \cdot 9 \pm 3 \cdot 8$ \\
\hline & Ad $\beta$-gal/leptin & $69 \cdot 7 \pm 5 \cdot 3$ & $69 \cdot 6 \pm 5 \cdot 4$ & $69 \cdot 4 \pm 5 \cdot 3$ & $69 \cdot 5 \pm 5 \cdot 3$ & $69 \cdot 0 \pm 5 \cdot 5$ & $68 \cdot 1 \pm 5 \cdot 5$ \\
\hline \multirow[t]{3}{*}{ Food intake (kcal/day) } & AdPTP1B/PBS & $5 \cdot 6 \pm 0 \cdot 2$ & $3.5 \pm 0.3^{*}$ & $4 \cdot 3 \pm 0.5$ & $4 \cdot 1 \pm 0.5$ & $4 \cdot 6 \pm 0.4$ & $4 \cdot 2 \pm 0.3$ \\
\hline & AdPTP1B/leptin & $5 \cdot 3 \pm 0 \cdot 4$ & $4 \cdot 0 \pm 0.4$ & $4 \cdot 4 \pm 0 \cdot 3$ & $4 \cdot 4 \pm 0 \cdot 2$ & $4 \cdot 0 \pm 0.5$ & $3.5 \pm 0.4$ \\
\hline & Ad $\beta$-gal/leptin & $5 \cdot 4 \pm 0.3$ & $3.9 \pm 0.6$ & $5 \cdot 1 \pm 0.6$ & $5 \cdot 0 \pm 0 \cdot 6$ & $3.9 \pm 0.7$ & $2 \cdot 8 \pm 0 \cdot 5^{\star}$ \\
\hline \multirow{3}{*}{ Glucose (mM) } & AdPTP1B/PBS & $18 \cdot 9 \pm 3 \cdot 6$ & $23 \cdot 7 \pm 4 \cdot 2$ & $24 \cdot 1 \pm 4 \cdot 1$ & $23 \cdot 9 \pm 4 \cdot 0$ & $25 \cdot 9 \pm 5 \cdot 0$ & $21 \cdot 9 \pm 4 \cdot 0$ \\
\hline & AdPTP1B/leptin & $20 \cdot 8 \pm 4 \cdot 1$ & $23 \cdot 1 \pm 3 \cdot 1$ & $20 \cdot 2 \pm 2 \cdot 6$ & $21 \cdot 7 \pm 3 \cdot 6$ & $16 \cdot 8 \pm 2 \cdot 3$ & $16 \cdot 9 \pm 1 \cdot 8$ \\
\hline & Ad $\beta$-gal/leptin & $22 \cdot 9 \pm 3 \cdot 4$ & $25.5 \pm 2.9$ & $23 \cdot 2 \pm 3 \cdot 4$ & $24 \cdot 1 \pm 2.9$ & $19 \cdot 3 \pm 3 \cdot 0$ & $13 \cdot 9 \pm 2 \cdot 0^{*}$ \\
\hline \multirow[t]{3}{*}{ Insulin (nM) } & AdPTP1B/PBS & $9 \cdot 9 \pm 4 \cdot 5$ & $6 \cdot 9 \pm 2 \cdot 3$ & Not & $7 \cdot 5 \pm 2 \cdot 7$ & $10 \cdot 4 \pm 3 \cdot 7$ & $7 \cdot 3 \pm 2 \cdot 5$ \\
\hline & AdPTP1B/leptin & $9 \cdot 7 \pm 3 \cdot 2$ & $11 \cdot 9 \pm 3 \cdot 2$ & measured & $10 \cdot 5 \pm 3 \cdot 2$ & $6 \cdot 7 \pm 2 \cdot 1$ & $3 \cdot 6 \pm 1 \cdot 3^{*}$ \\
\hline & Ad $\beta$-gal/leptin & $12 \cdot 5 \pm 5 \cdot 1$ & $12 \cdot 1 \pm 1 \cdot 4$ & & $13 \cdot 7 \pm 3 \cdot 2$ & $9 \cdot 3 \pm 3 \cdot 2$ & $4 \cdot 9 \pm 1 \cdot 6^{*}$ \\
\hline
\end{tabular}

AdPTP1B/PBS: $n=4$; AdPTP1B/leptin: $n=6$; Adß-gal/leptin: $n=7$.

${ }^{\star} P \leq 0.05$ vs day 0 of same treatment group.

(Cheng et al. 2002, Zabolotny et al. 2002), we have found that, in addition to the well-characterized function of PTP1B as a negative regulator of insulin signaling, PTP1B is also a negative regulator of leptin-signaling pathways. The dual role of PTP1B as an inhibitor of insulin and leptin signaling implicates PTP1B as a common mediator of the resistance to both hormones and thus a potential link between obesity and diabetes (Johnson et al. 2002, Zhang \& Lee 2003).

In this study we sought to determine if PTP1B might contribute to the onset of insulin and leptin resistance. To model human obesity in mice, we fed mice an HF diet for 72 days. As expected, relative to mice on an LF diet, HF-fed mice gained more weight, consumed more calories and were hyperglycemic, hyperinsulinemic and hyperleptinemic by 35 days into the study. Increased body weight gain of HF-fed mice relative to LF-fed mice started at approximately 18 days into the diets while measurable changes in food intake were detected by day 16 , likely indicating the development of resistance to the satiety actions of leptin. The mechanism by which leptin resistance develops following regular consumption of an HF diet is unknown. Some factors that may contribute include leptin receptor down-regulation, reduced leptin transport into the brain, or activation of suppressors of cytokine signaling which inhibit leptin signaling through JAK-STAT (Bjorbaek et al. 1998, Friedman \& Halaas 1998, Ahima \& Flier 2000).

We explored the hypothesis that up-regulation of PTP1B may be involved in the development of leptin resistance. After 72 days on the diets, at which point HF-fed mice displayed insulin resistance and resistance to leptin-mediated reductions in caloric consumption, PTP1B expression was elevated in adipose tissue, muscle and most dramatically in the liver of HF-fed mice relative to the LF-fed group. Consistent with the notion that PTP1B is a negative regulator of insulin signaling (Ahmad et al. 1995, Elchebly et al. 1999, Zinker et al. 2002), we found that the elevated hepatic expression of PTP1B was associated with a reduced ability of insulin to activate IR phosphorylation in hepatocytes. The resistance to leptin-mediated suppression of food intake in the HF-fed C57BL/6 mice may arise from increased PTP1B expression in the tissues investigated or alternatively may be mediated by other mechanisms and locations such as the central nervous system. To assess what contribution elevated hepatic PTP1B might have in the development of leptin resistance, we overexpressed PTP1B in the livers of leptin-deficient $o b / o b$ mice. These animals are typically severely insulin resistant despite lower than normal hepatic levels of PTP1B (Lam et al. 2004) and display enhanced sensitivity to both the weight-reducing and glucoselowering actions of leptin (Campfield et al. 1995, Halaas et al. 1995, Pelleymounter et al. 1995, Stephens et al. 1995). Eight-month-old $o b / o b$ mice weighed approximately twice that of wild-type mice and displayed elevated fasting plasma glucose and insulin concentrations. Over-expression of PTP1B in the liver did not alter body weight, food consumption or plasma concentrations of glucose during the study period. Furthermore, it did not block leptin-mediated reductions of plasma insulin. Leptin can act to curtail insulin secretion by processes that involve central actions as well as direct effects of leptin on pancreatic $\beta$-cells (Kieffer \& Habener 2000), in addition to improvements in insulin sensitivity (Lam et al. 2004). In the present study, the leptin-induced suppression in plasma insulin occurred 

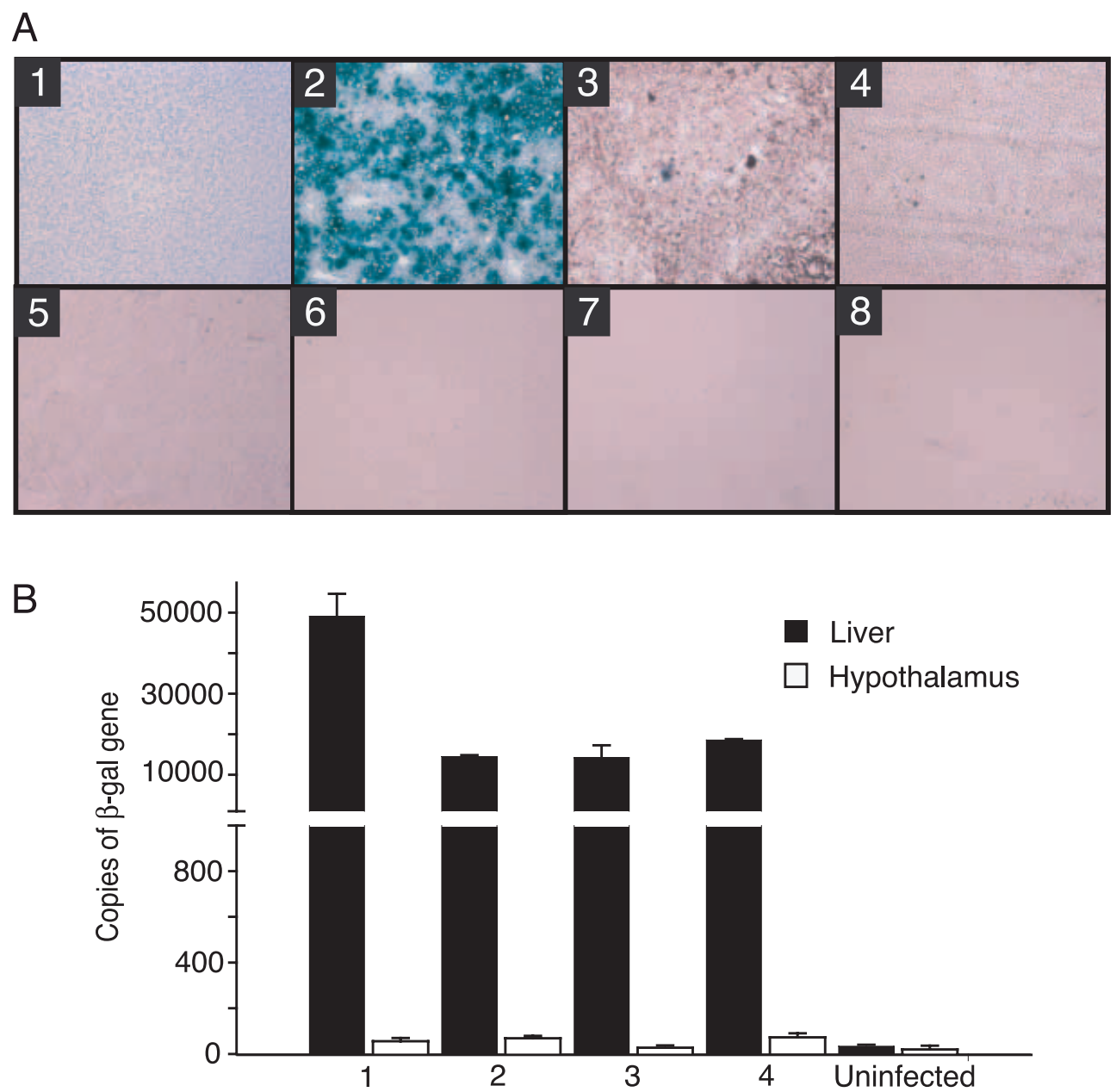

Figure 5 Distribution of $A d \beta$-gal administered by tail vein injection. (A) Ob/ob mice received a single injection of either saline or $1 \times 10^{9}$ PFU Ad $\beta$-gal via the tail vein. Eight days post administration, liver tissue was immediately imbedded in Tissue-Tek OCT compound and stained for $\beta$-gal expression. Panel 1 shows a representative image of liver tissue from uninfected mice. Panels $2-8$ are representative images of tissues taken from Ad $\beta$-gal-infected mice: (2) liver, (3) pancreas, (4) brain, (5) muscle, (6) heart, (7) kidney and (8) spleen. Magnification is $100 \times$ for all images. (B) Liver and hypothalamus tissue were harvested from CD1 mice either uninfected or 7 days after tail vein injection with $1 \times 10^{9}$ PFU Ad $\beta$-gal. Genomic DNA was prepared from the tissues and used as template for TaqMan real-time PCR analysis. The amount of template used in reactions varied between the mice (but was constant for both tissues) according to the amount of DNA obtained from the hypothalamus tissue: $118 \mathrm{ng}$ for mouse 1, $28 \mathrm{ng}$ for mouse 2, $18 \mathrm{ng}$ for mouse 3 and $48 \mathrm{ng}$ for mouse 4 . Results are the mean copy number \pm S.D. ( $n=2$ reactions).

even in the presence of elevated plasma glucose. However, elevated hepatic PTP1B expression markedly impaired the ability of leptin to reduce plasma glucose levels. The mechanism by which leptin reduces blood glucose likely involves enhanced glucose uptake by peripheral tissues and inhibition of hepatic glucose production (Barzilai et al. 1997, Kamohara et al. 1997, Rossetti et al. 1997, Chinookoswong et al. 1999, Anderwald et al. 2002). While we have previously demonstrated that leptin can improve insulin sensitivity by direct actions on hepatocytes (Lam et al. 2004), we cannot exclude the possibility that the improvements in hepatic insulin sensitivity following leptin injection observed in this study are also centrally mediated. Indeed, it has recently been demonstrated that intracerebroventricular administration of leptin improves hepatic insulin sensitivity, presumably via central nervous system pathways (Asilmaz et al. 2004). However, it is noteworthy that gold thioglucose destruction of hypothalamic leptin receptor-expressing neurons in $\mathrm{PTP}_{1 \mathrm{~B}^{-/-}}$mice has no impact on the enhanced insulin sensitivity of these animals (Zabolotny et al. 2002). 
A

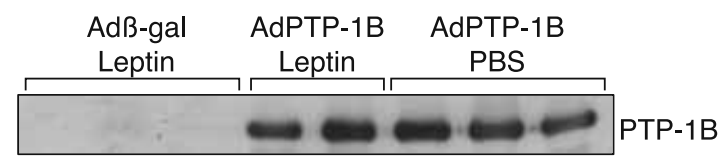

B
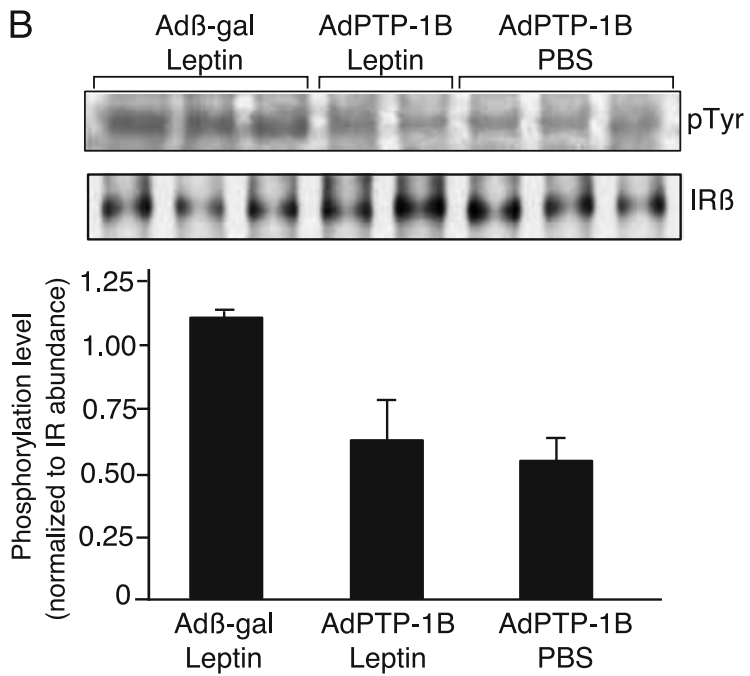

Figure 6 PTP1B over-expression in liver decreases insulin-stimulated IR phosphorylation in leptin-treated mice. $O b / o b$ mice on day 6 after infection with Ad $\beta$-gal or AdPTP1B were treated with leptin or PBS for 2 days. Mice were fasted for $6 \mathrm{~h}$ then given an injection of insulin $(25 \mathrm{mU} / \mathrm{kg})$ via the hepatic portal vein. Two minutes following the insulin infusion, liver tissue was harvested and protein lysates prepared and were either (A) immunoblotted with anti-PTP1B antibody or (B) immunoprecipitated with antibody to IR. Phosphorylation of IR was assessed by immunoblotting with anti-phosphotyrosine antibody. Membranes were stripped and reprobed with IR antibody. Representative immunoblots depicting tyrosine phosphorylation of a $95 \mathrm{kDa}$ IR $\beta$-subunit are shown as well as the mean intensities \pm S.E.M. (arbitrary units) of phosphotyrosine expression, corrected for total IR protein \pm S.E.M. $(n=2$ or 3$)$.

Therefore, leptin signaling in the hypothalamus does not appear to be required for the regulation of insulin sensitivity by PTP1B. Our findings have confirmed that the liver is an important target organ for the glucose-lowering action of leptin and provide novel evidence that this pathway is negatively regulated by hepatic PTP1B.

Interestingly, increased hepatic PTP1B expression in $o b / o b$ mice was also able to inhibit leptin-induced satiety. In control $a b / o b$ mice receiving Ad $\beta$-gal, exogenous leptin reduced food consumption by approximately $50 \%$ after 2 days of treatment. However, in AdPTP1B-treated mice, PTP1B over-expression in hepatocytes reduced the effectiveness of leptin in suppressing food consumption by more than half. Intriguingly, liver-specific disruption of STAT3 causes weight gain in addition to hyperglycemia and hyperinsulinemia (Inoue et al. 2004). As we have previously reported, leptin promotes phosphorylation and nuclear translocation of STAT3 in hepatocytes (Lam et al. 2004); perhaps this signaling pathway mediates the peripheral effects of leptin on food intake and glucose homeostasis. While traditionally the regulatory effect of leptin on food intake is viewed as a response to direct central actions of leptin (Vaisse et al. 1996, Friedman \& Halaas 1998, Ahima \& Flier 2000, Cohen et al. 2001), our results have provided the first evidence that leptin action in the liver can regulate feeding behavior. Furthermore, our findings are supportive of the notion of Zabolotny et al. (2002) that a large portion of the influence of PTP1B on body mass regulation must be outside of leptin-responsive hypothalamic neurons, since elimination of these in $\mathrm{PTP}_{1} \mathrm{~B}^{-/-}$mice has no effect on the insulin hypersensitivity of the animals and only partially reverses the protection from dietinduced obesity. If indeed leptin can regulate food intake as a result of direct actions of leptin on hepatocytes, analysis of mice with a chronic liver-specific reduction in leptin receptor expression suggests that, with life-long deficiency, normal control of food intake can be maintained by other redundant pathways (Cohen et al. 2001). Although the liver has long been implicated in the control of food intake and body weight regulation, the pathways and signaling molecules involved have not been definitively established (for review see Langhans 2003). One theory is that an increase in glucose utilization can produce a satiating effect (Langhans et al. 2001). Sensors in the liver that detect changes in fuel metabolism may trigger a signal in vagal afferents that act centrally to inhibit food intake (Langhans et al. 1985). The lipolytic effect of leptin in the liver, depleting triglyceride content and increasing free fatty acid oxidation (Shimabukuro et al. 1997, Lee et al. 2001, Cohen et al. 2002), may provide an alternate satiety signal that could also be relayed through vagal afferents (Langhans et al. 1985). Recently, induction of leptin receptor expression in the liver by leptin and food deprivation was reported, in association with a large increase in a soluble form of leptin receptor that might bind leptin and thereby regulate the bioavailability of leptin to satiety centers (Cohen et al. 2005). Whether leptin signaling through a PTP1B-sensitive pathway suppresses food intake via a vagally mediated pathway or perhaps via altered production of a soluble leptin receptor remains to be determined.

In summary, our findings have demonstrated that HF feeding leading to insulin and leptin resistance is associated with increased PTP1B protein expression in liver, muscle and adipose tissue. We also found that over-expression of PTP1B in the liver curtails the ability of leptin to lower blood glucose levels and suppress food intake. We therefore propose that leptin signaling in the liver is important not only in regulating glucose homeostasis but also food intake and energy balance. Our discovery that PTP1B inhibits these actions of leptin indicates that hepatic PTP1B could be important 
in the development of insulin and leptin resistance, and thus a link in the pathogenesis of obesity and diabetes. We previously determined that exposure of hepatocytes to leptin can increase PTP1B expression (Lam et al. 2004). Taken together, we speculate that a diet high in fat can promote diabetes associated with obesity by elevating fat stores and thus circulating leptin levels (Ahima et al. 1996, Unger 2002), which may initially protect non-adipocytes from steatosis and lipotoxicity (Unger 2002), but eventually precipitates both insulin and leptin resistance through increased expression of PTP1B. Our findings suggest that strategies aimed at suppressing PTP1B specifically in the liver could improve both hepatic insulin and leptin sensitivity and thereby improve both glucose homeostasis and regulation of food intake. Further understanding of the role of PTP1B in the development of leptin and insulin resistance may provide insights into the pathophysiology of obesity and diabetes and reveal novel therapeutic strategies with which to treat these diseases.

\section{Funding}

Funding support from the Canadian Institutes of Health Research (GIHR) to T J K is gratefully acknowledged. TJ K was supported by Alberta Heritage Foundation for Medical Research (AHFMR) and Canadian Diabetes Association (CDA) scholarships and a Juvenile Diabetes Research Foundation Career Development Award. NTL was supported by a Natural Sciences and Engineering Research Council scholarship and an AHFMR studentship. A T C was supported by AHFMR and CDA fellowships. The authors declare that there is no conflict of interest that would prejudice the impartiality of this scientific work.

\section{References}

Ahima RS \& Flier JS 2000 Leptin. Annual Review of Physiology 62 413-437.

Ahima RS, Prabakaran D, Mantzoros C, Qu D, Lowell B, Maratos-Flier E \& Flier JS 1996 Role of leptin in the neuroendocrine response to fasting. Nature 382 250-252.

Ahmad F, Li PM, Meyerovitch J \& Goldstein BJ 1995 Osmotic loading of neutralizing antibodies demonstrates a role for protein-tyrosine phosphatase $1 \mathrm{~B}$ in negative regulation of the insulin action pathway. Fournal of Biological Chemistry 270 20503-20508.

Anderwald G, Muller G, Koca G, Furnsinn C, Waldhausl W \& Roden M 2002 Short-term leptin-dependent inhibition of hepatic gluconeogenesis is mediated by insulin receptor substrate-2. Molecular Endocrinology 16 1612-1628.

Asilmaz E, Cohen P, Miyazaki M, Dobrzyn P, Ueki K, Fayzikhodjaeva G, Soukas AA, Kahn CR, Ntambi JM, Socci ND et al. 2004 Site and mechanism of leptin action in a rodent form of congenital lipodystrophy. Fournal of Clinical Investigation $\mathbf{1 1 3}$ $414-424$.
Barzilai N, Wang J, Massilon D, Vuguin P, Hawkins M \& Rossetti L 1997 Leptin selectively decreases visceral adiposity and enhances insulin action. Fournal of Clinical Investigation 100 3105-3110.

Bjorbaek C, Elmquist JK, Frantz JD, Shoelson SE \& Flier JS 1998 Identification of SOCS-3 as a potential mediator of central leptin resistance. Molecular Cell 1 619-625.

Campfield LA, Smith FJ, Guisez Y, Devos R \& Burn P 1995 Recombinant mouse OB protein: evidence for a peripheral signal linking adiposity and central neural networks. Science 269 546-549.

Cheng A, Uetani N, Simoncic PD, Chaubey VP, Lee-Loy A, McGlade CJ, Kennedy BP \& Tremblay ML 2002 Attenuation of leptin action and regulation of obesity by protein tyrosine phosphatase 1B. Developmental Cell 2 497-503.

Chinookoswong N, Wang JL \& Shi ZQ 1999 Leptin restores euglycemia and normalizes glucose turnover in insulin-deficient diabetes in the rat. Diabetes $\mathbf{4 8}$ 1487-1492.

Cohen P, Zhao C, Cai X, Montez JM, Rohani SC, Feinstein P, Mombaerts P \& Friedman JM 2001 Selective deletion of leptin receptor in neurons leads to obesity. Fournal of Clinical Investigation $1081113-1121$.

Cohen P, Miyazaki M, Socci ND, Hagge-Greenberg A, Liedtke W, Soukas AA, Sharma R, Hudgins LC, Ntambi JM \& Friedman JM 2002 Role for stearoyl-CoA desaturase-1 in leptin-mediated weight loss. Science 297 240-243.

Cohen P, Yang G, Yu X, Soukas AA, Wolfish CS, Friedman JM \& $\mathrm{Li} \mathrm{C} 2005$ Induction of leptin receptor expression in the liver by leptin and food deprivation. Fournal of Biological Chemistry.

Egawa K, Maegawa H, Shimizu S, Morino K, Nishio Y, Bryer-Ash M, Cheung AT, Kolls JK, Kikkawa R \& Kashiwagi A 2001 Protein-tyrosine phosphatase-1B negatively regulates insulin signaling in 16 myocytes and Fao hepatoma cells. Fournal of Biological Chemistry 276 10207-10211.

Elchebly M, Payette P, Michaliszyn E, Cromlish W, Collins S, Loy AL, Normandin D, Cheng A, Himms-Hagen J, Chan CC et al. 1999 Increased insulin sensitivity and obesity resistance in mice lacking the protein tyrosine phosphatase-1B gene. Science $\mathbf{2 8 3}$ $1544-1548$.

Friedman JM \& Halaas JL 1998 Leptin and the regulation of body weight in mammals. Nature $395763-770$.

Ghilardi N \& Skoda RC 1997 The leptin receptor activates janus kinase 2 and signals for proliferation in a factor-dependent cell line. Molecular Endocrinology 11 393-399.

Gum RJ, Gaede LL, Koterski SL, Heindel M, Clampit JE, Zinker BA, Trevillyan JM, Ulrich RG, Jirousek MR \& Rondinone CM 2003 Reduction of protein tyrosine phosphatase 1B increases insulin-dependent signaling in ob/ob mice. Diabetes 52 21-28.

Halaas JL, Gajiwala KS, Maffei M, Cohen SL, Chait BT, Rabinowitz D, Lallone RL, Burley SK \& Friedman JM 1995 Weight-reducing effects of the plasma protein encoded by the obese gene. Science 269 543-546.

Inoue $\mathrm{H}$, Ogawa W, Ozaki M, Haga S, Matsumoto M, Furukawa K, Hashimoto N, Kido Y, Mori T, Sakaue H et al. 2004 Role of STAT-3 in regulation of hepatic gluconeogenic genes and carbohydrate metabolism in vivo. Nature Medicine 10 168-174.

Johnson TO, Ermolieff J \& Jirousek MR 2002 Protein tyrosine phosphatase 1B inhibitors for diabetes. Nature Reviewes in Drug Discovery 1 696-709.

Kamohara S, Burcelin R, Halaas JL, Friedman JM \& Charron MJ 1997 Acute stimulation of glucose metabolism in mice by leptin treatment. Nature $389374-377$.

Kaszubska W, Falls HD, Schaefer VG, Haasch D, Frost L, Hessler P, Kroeger PE, White DW, Jirousek MR \& Trevillyan JM 2002 Protein tyrosine phosphatase $1 \mathrm{~B}$ negatively regulates leptin signaling in a hypothalamic cell line. Molecular and Cellular Endocrinology 195 109-118.

Kieffer TJ \& Habener JF 2000 The adipoinsular axis: effects of leptin on pancreatic beta-cells. American fournal of Physiology; Endocrinology and Metabolism 278 E1-E14. 
Klaman LD, Boss O, Peroni OD, Kim JK, Martino JL, Zabolotny JM, Moghal N, Lubkin M, Kim YB, Sharpe AH et al. 2000 Increased energy expenditure, decreased adiposity, and tissue-specific insulin sensitivity in protein-tyrosine phosphatase 1B-deficient mice. Molecular and Cellular Biology 20 5479-5489.

Lam NT, Lewis JT, Cheung AT, Luk CT, Tse J, Wang J, Bryer-Ash M, Kolls JK \& Kieffer TJ 2004 Leptin increases hepatic insulin sensitivity and protein tyrosine phosphatase 1B expression. Molecular Endocrinology 18 1333-1345.

Langhans W 2003 Role of the liver in the control of glucose-lipid utilization and body weight. Current Opinion in Clinical Nutrition and Metabolic Care 6 449-455.

Langhans W, Egli G \& Scharrer E 1985 Selective hepatic vagotomy eliminates the hypophagic effect of different metabolites. Fournal of the Autonomic Nervous System 13 255-262.

Langhans W, Grossmann F \& Geary N 2001 Intrameal hepaticportal infusion of glucose reduces spontaneous meal size in rats. Physiology and Behavior 73 499-507.

Lee Y, Wang MY, Kakuma T, Wang ZW, Babcock E, McCorkle K, Higa M, Zhou YT \& Unger RH 2001 Liporegulation in diet-induced obesity. The antisteatotic role of hyperleptinemia. Fournal of Biological Chemistry 276 5629-5635.

Murakami T, Yamashita T, Iida M, Kuwajima M \& Shima K 1997 A short form of leptin receptor performs signal transduction. Biochemical and Biophysical Research Communications 231 26-29.

Myers MP, Andersen JN, Cheng A, Tremblay ML, Horvath CM, Parisien JP, Salmeen A, Barford D \& Tonks NK 2001 TYK2 and JAK2 are substrates of protein-tyrosine phosphatase 1B. Fournal of Biological Chemistry 276 47771-47774.

Olefsky J 1983 Obesity. In Harrison's Principles of Internal Medicine, Eds. RG Petorsdorf, RD Adam, F Braunwald, KJ Isselbacher, JB Marlin \& JD Wilson. pp 440-446. New York: McGraw-Hill.

Pelleymounter MA, Cullen MJ, Baker MB, Hecht R, Winters D, Boone T \& Collins F 1995 Effects of the obese gene product on body weight regulation in ob/ob mice. Science $269540-543$.

Rossetti L, Massillon D, Barzilai N, Vuguin P, Chen W, Hawkins M, Wu J \& Wang J 1997 Short term effects of leptin on hepatic gluconeogenesis and in vivo insulin action. Fournal of Biological Chemistry 272 27758-27763.

Shimabukuro M, Koyama K, Chen G, Wang MY, Trieu F, Lee Y, Newgard CB \& Unger RH 1997 Direct antidiabetic effect of leptin through triglyceride depletion of tissues. PNAS $\mathbf{9 4}$ $4637-4641$.

Stephens TW, Basinski M, Bristow PK, Bue-Valleskey JM, Burgett SG, Craft L, Hale J, Hoffmann J, Hsiung HM, Kriauciunas A et al. 1995 The role of neuropeptide $\mathrm{Y}$ in the antiobesity action of the obese gene product. Nature 377 530-532.

Unger RH 2002 Lipotoxic diseases. Annual Review of Medicine $\mathbf{5 3}$ 319-336.

Vaisse C, Halaas JL, Horvath CM, Darnell JE Jr, Stoffel M \& Friedman JM 1996 Leptin activation of Stat3 in the hypothalamus of wild-type and ob/ob mice but not db/db mice. Nature Genetics 14 95-97.

Wang J, Cheung AT, Kolls JK, Starks WW, Martinez-Hernandez A, Dietzen D \& Bryer-Ash M 2001 Effects of adenovirus-mediated liver-selective overexpression of protein tyrosine phosphatase- $1 \mathrm{~b}$ on insulin sensitivity in vivo. Diabetes Obesity Metabolism 3 367-380.

Zabolotny JM, Bence-Hanulec KK, Stricker-Krongrad A, Haj F, Wang Y, Minokoshi Y, Kim YB, Elmquist JK, Tartaglia LA, Kahn BB et al. 2002 PTP1B regulates leptin signal transduction in vivo. Developmental Cell 2 489-495.

Zhang ZY \& Lee SY 2003 PTP1B inhibitors as potential therapeutics in the treatment of type 2 diabetes and obesity. Expert Opinion in Investigating Drugs 12 223-233.

Zinker BA, Rondinone CM, Trevillyan JM, Gum RJ, Clampit JE, Waring JF, Xie N, Wilcox D, Jacobson P, Frost L et al. 2002 PTP1B antisense oligonucleotide lowers PTP1B protein, normalizes blood glucose, and improves insulin sensitivity in diabetic mice. PNAS 99 11357-11362.

Received in final form 2 November 2005

Accepted 18 November 2005

Made available online as an Accepted Preprint 28 November 2005 